Journal of Animal and Veterinary Advances 9 (3): 446-451, 2010

ISSN: $1680-5593$

(C) Medwell Journals, 2010

\title{
Consumer Dispositions Towards Organic Food: The Example of Kahramanmaras/Turkey
}

\author{
Tulin Cicek and Ahmet Kartalkanat \\ Department for Animal Production, Faculty of Agricultural, \\ Kahramanmaras Sutcu Imam University, Kahramanmaras, Turkey
}

\begin{abstract}
The demand for healthy products has been grown among consumers over the last years. As a consequence of this demand organic farming, which is an environmentally compatible production system has spread out rapidly. Organic farming is an approach in farming that targets to generate systems, which research regarding to holistic, ethical, global and economic principles. While, products of organic farming receive better acceptance in developed countries, demand for them remains limited in developing countries such as Turkey. In order to find out, in what direction consumer demands for organic farming exist, a survey was conducted in the most frequented supermarkets in Kahramanmaras, the capital city of Kahramanmaras Province/Turkey. A total of 201 men and 101 women took part in this survey. Forty three percent of the participants had a high school degree and $34 \%$ of the participants had a graduate degree. Sixty four percent of the participants connected the slow pace, at which organic products spread with a lack of awareness in consumers. Thirty nine percent of the participants said that they had heard about organic products on TV and $95 \%$ of the participants pointed out that they would not like to consume products, which contain genes of human or microrganisms.
\end{abstract}

Key words: Organic farming, sustainability, consumer dispositions, Kahramanmaras, Turkey

\section{INTRODUCTION}

Organic farming as a production form, in which each stage of the production is recorded, uses organic-based material instead of any chemicals and therefore does not harm environment, humans and animals (Yanmaz, 2001). Organic farming is carried out worldwide on an area of 24 million ha. Of these, $42 \%$ are in Oceania, 23 and $24.2 \%$ in Europe and South America, respectively. The countries with the biggest area used for organic farming are Australia, Argentina and Italy (Yussefi, 2004). The market for organic products, which amounted to 20 billion dollars in 2005 , increases every day. The main reason for this development is the fact that consumers demand for healthier and more qualitative products. Moreover, several chemicals are used in conventional farming. Among those the most important are probiotics and growth hormones in animal production and pesticides in plant production. Conventional animal production is focused on factors that are not centered up animal welfare or health. Especially, in developed countries however, consumers demand for better conditions for animals used in meat production. Namely animal rights have become a primary subject of discussion (Lund and Algers, 2003).
A limitation in variety of products and high prices are the main problems of products coming from organic farming. The grade of consumption depends on the grade of development in society (Demiryurek, 2004). A recent increase in supermarkets and shops offering organic products, however, has affected domestic consumption positively. Consumers who buy organic products generally have big incomes are middle-aged, educated and more aware of health risks.

Different social-economic struictures in society are reflected in consumer dispositions. Differences of habits of nutrition in society can be displayed through geographic and climate conditions, as well as level of agriculture, animal production and industrialization. (Vindigni et al., 2002). Moreover, factors such as the distribution of communication tools effect and change habits of nutrition.

Now-a-days, a great majority of society puts forms of plant and animal production into question and instead of industrial production healthy and environment-friendly production forms come to the fore. Such a production form, which is called ecological or organic farming is expected to meet these demands (Browne et al., 2000).

The reason for quite a great demand for organic products is the fact that in conventional plant and animal

Corresponding Author: Tulin Cicek, Department for Animal Production, Faculty of Agricultural, Kahramanmaras Sutcu Imam University, Kahramannmaras, Turkey 
producion methods are applied that are harmful for health and have negative effects on the environment. Therefore, consumers accept more and more production forms that do not harm human health and are friendly to the environment (Armagan and Ozdogan, 2005). Piyasiri and Ariyawordara (2002), reported that $99 \%$ of the consumers, who took part in their study thought that organic products are safer and more healthy than conventional products. Since, in conventional production the focus is on mass and economic production, health criteria of organically balanced and qualitative production are less important. For these reasons conventional farming has started to be seen as a production form that harms humans, animals and the environment.

Chemical additives and Genetically Modified (GM) organisms are widely used in conventional farming. Most consumers do not want to consume GM foods (Demir and Pala, 2007). Agricultural drug residue in non-organic foods, which is deposited in adipose tissue and transfered to newborn babies with breast milk, causes several diseases, in particular cancer. Organic farming is currently carried out in approximately, 130 countries and this figure increases every day. However, the percentage of organic products in food sales amounts to only $1-4 \%$. This study targets to document consumer dispositions towards consumption of rapidly spreading organic farming products.

\section{MATERIALS AND METHODS}

The material for this study is the original data of a survey conducted in the most frequented supermarkets in Kahramanmaras/Turkey between 5 and 20 February 2008. According to the registration of Kahramanmaras Address Office, 385.672 people lived in Kahramanmaras in 2008. When, determining the number of participants to take part in the survey, information on same properties in the statistical population was used to chose a random sample. According to that the size of the sample was assessed at 298.

Most of the survey questions, which were presented to a total of 302 respondents were designed as multiple choice questions.

The survey included a total of 10 questions related to products of organic farming. First the respondents were asked to give personal information such as age, sex, education, marital status and income. During the preparation of the questions, it was attended to find out how consumers approach to this worldwide new production system.

The obtained data were statistically analyzed through Khi-Kare test in SPSS 15,0 statistics program.
Khi-Kare test is a program that is used to evaluate counted data and therefore frequently used in survey evaluations.

\section{RESULTS AND DISCUSSION}

Personal information on respondents: A total of 201 men and 101 women took part in the survey. Thirteen percent graduated from primary school, $43 \%$ from secondary school and $44 \%$ from university (Table 1 ). This shows that the educational level of the respondents is high. The age groups of under 20 and over 50 were smaller than the other age groups. Sixty percent of the respondents were male and $34 \%$ were female.

A great deal of the respondents belong to the middle-income group (Table 2) $65 \%$ of them have an income that ranges between $\$ 400$ and $\$ 1000$. About $18 \%$ stated an income of under $\$ 400$.

Answers related to educational situation: Total 19\% of the respondents answered no to the question: Have you ever heard about organic farming products? If so, where did you hear about them? Of these, $28.5 \%$ graduated from primary school, $53.1 \%$ from secondary school and $18 \%$ from university. Of those who answered yes to the question $13 \%$ stated that they had received information from the Internet, $39 \%$ from TV, $4.3 \%$ from the radio, $12 \%$ from newspapers and $13 \%$ from friends. Forty one percent of those, who read about organic farming on the Internet and $27 \%$ of those, who saw about organic farming on TV graduated from university, while $44.5 \%$ of those who graduated from secondary school and $12.6 \%$ of those, who graduated from primary school saw about organic farming on TV. It was found out that respondents with a

Table 1: Personal information on respondents (\%)

\begin{tabular}{lc}
\hline Parameters & No. of individual \\
\hline Education & 13 \\
Primary school & 43 \\
Secondary school & 44 \\
University & \\
Age & 10 \\
$>20$ & 43 \\
$21-30$ & 20 \\
$31-40$ & 18 \\
$41-50$ & 9 \\
$50<$ & \\
Sex & 54 \\
Male & 46 \\
Female & \\
& \\
Table 2: Respondents' monthly income $(\$)$ & Percentage \\
\hline Monthly income & 18 \\
$<400$ & 65 \\
$401-1000$ & 10 \\
$1001-2000$ & 7 \\
$2001<$ & \\
\hline
\end{tabular}




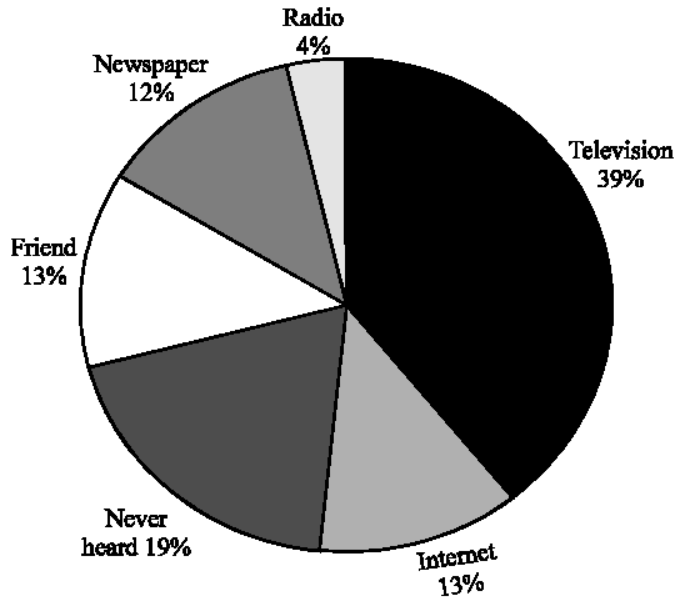

Fig. 1: Where have you heard about organic farming?

higher level of education received information about organic farming from the Internet, while respondents with a lower level of education saw about organic farming on TV (Fig. 1).

About $13.5 \%$ off the respondents answered no to the question: Do you think organic farming products are necessary? While, the rest said that it was necessary. Forty nine percent of the participants who said that organic products were not necessary had a secondary school graduation. Of the respondents who graduated from primary school, $22.5 \%$ did not see the need for organic products while, 77.5 did. Ninety percent of university graduates stated that organic products were necessary in order to eat a healthier diet or not to pollute the environment. Level of education not with standing, a great majority of the respondents agreed on the idea of organic products being necessary.

Forty nine percent of the respondents said that they checked for additives, when they bought food. About 22.5 pointed out that they consumed certain makes, $22 \%$ that they preferred cheap products and $4 \%$ that the i did not care about ingredients. The group of consumers, who prefer cheap products consists of $70 \%$ primary and secondary school graduates. Fifty six percent of those, who prefer certain marks graduated from secondary school, $11 \%$ from primary school and $33 \%$ from university. An increasing consumer disposition towards healthier products with higher education can be observed. On the other hand, a lower level of education leads to a preference for cheaper products. This stresses how important education is for a healthy diet.

Sixty six percent answered yes to the question: Are organic farming products produced in Turkey? Six percent said that they were not produced and $27.5 \%$ did not know if they were produced or not. About $31.5 \%$ of the respondents who thought that organic products were not produced in Turkey graduated from primary school, $47 \%$ from secondary school and 21.5 from university. Eighteen percent of primary school graduates, $56 \%$ of high school graduates and $26 \%$ of university graduates did not know if organic products were produced in Turkey or not. It was found out that a higher level of education leads to more knowledge about production in organic farming.

Asked how they could recognize if a product was organic or not, $56 \%$ of the respondents said that they looked at the logo of the product, $19 \%$ smelled and $25 \%$ asked the staff.

Seventy three percent of the respondents said that Genetically Modified (GM) organisms were used in order increase yield in farming when asked: What is the reason for the use of Genetically Modified (GM) organisms in agriculture? Twenty seven percent saw the reason in the attempt of seed companies to monopolize. Fifty four percent of those, who said that reason was to increase yield graduated from primary school or secondary school. The rest were graduates from high school or university. While, $49 \%$ of those, who said the reason was that seed companies request to monopolize were secondary school graduates, $23 \%$ graduated from university.

Ninety five percent of all participants in the survey pointed out that they did not want to consume products containing genes of humans or microorganisms. Five percent saw no problem in consuming such products. Of those, $35 \%$ were graduates from university and $35 \%$ from secondary school. Of those who do not want to consume such products, $13 \%$ graduated from primary school, $44 \%$ from secondary school and $43 \%$ from university.

Five percent of the respondents said that the reason for the slow spread of organic products was that they were not necessary, while $25 \%$ said that the reason were high prices of organic products. Sixty four percent explained the reason with insufficient consumers' awareness about organic farming and $6 \%$ with a shortage of products. What strikes here is the fact that most respondents see the reason in insufficient raise of awareness. Fifty six percent of those who graduated from primary school thought so and $15 \%$ of the same group did not consider organic products necessary.

Fifty nine percent of the respondents thought that genetically modified products were produced in Turkey while, $49 \%$ did not. Sixty seven percent of these were not university graduates. Fifty percent of those who said that genetically modified products were produced in Turkey were university graduates.

In America it is regulated by law that children from the age of 0-2 have an organic diet. Asked, if there should 
be such a regulation in Turkey, $81 \%$ said that there should be such a regulation by law, while $19 \%$ said there should not be. Of those, who gave a positive answer to this question, $60 \%$ graduated from primary school, while $40 \%$ of this group gave a negative answer. For those, who graduated from high school the percentages were 81 and $19 \%$, respectively and for university graduates 89 and $11 \%$, respectively.

Conumers' answers according to age group: Ninteen percent of the respondents were under 20 or over 50 years old. Eight percent of those who read about organic farming on the Internet were between 10 and 20 years old, $40 \%$ between 21 and $30,22 \%$ between 31 and $40,24 \%$ between 41 and 50 and $6 \%$ over 50 . A great deal of young people pointed out that they had received information about organic farming via the Internet.

Thirty eight percent of those who said that organic farming products were necessary belong to the group of 21-30, while $40 \%$ disagreed.

Asked what they attended to when they bought organic farming products $46 \%$ of the age group $20-31$ said that they checked for additives, $4 \%$ that they did not check for additives, $33 \%$ said that they preffered certain makes and $17 \%$ said they looked at the price. For the age group the percentage is $37,4,25$ and $34 \%$, respectively.

Forty one percent of the age group $21-30,16 \%$ of the age group $10-20,30 \%$ of the age group $31-50$ and $13 \%$ of the age group over 50 said that they did not know if organic products were produced in Turkey. Forty two percent of the age group 21-30 said that organic products were produced in Turkey.

Among the 21-30 years old consumers who took part in the survey $75 \%$ said that the reason for the use of genetically modified organisms was to increase yield in agriculture, while $25 \%$ explained the use with the intention of seed companies to monopolize in their sector.

Asked if they would like to consume products that contain genetically modified organisms, $6 \%$ of the respondents, who are between 21 and 30 years old said that they would like, while $94 \%$ would not.

The same questions was answered with no at a rate of $100 \%$ in the age groups $41-50$ and over 50 .

Sixty seven percent of the 21-30 years old respondents saw the reason for the slow spread of organic farm products in a lack of awareness with the consumers, $25 \%$ in the high costs for such products, $4 \%$ in the statement that these products were not necessary and $4 \%$ in a narrow variety of products. In the group of over 50 the percentages are $17,17,58$ and $8 \%$, respectively.

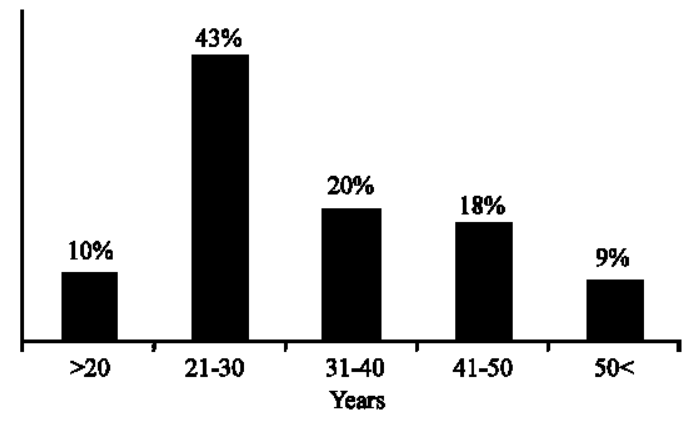

Fig. 2: Percentage of respondents who have not heard about organic farming products according to age groups

Forty nine percent of the age group $21-30,19 \%$ of the age group $31-40$ and $5 \%$ of the age group over 50 said that genetically modified products were not made known. The majority of those, who said that they were made known was in the group of 21-30 with a rate of $40 \%$. With increasing age this rate decreases: only $9 \%$ of the over $50 \mathrm{~s}$ answered the question with yes. In America it is regulated by law that children from the age of $0-2$ have an organic diet.

Asked if there should be such a regulation in Turkey, $44 \%$ of the age group $21-30,21 \%$ of the age group $31-40,20 \%$ of the age group $41-50$ and $6 \%$ of the over 50 said that there should be such a regulation by law 201 male and 101 female respondends took part in the survey.

Of these, 173 were married, 117 single and 12 widow(er)s. Regarding to the age, a great deal of the participants was young. The consumers were depending on age and education quite well-informed. Most consumers stated that they were informed about the developing organic farming. Seventy four percent of the married respondents said that they saw about organic farming on TV (Fig. 2).

Thirty percent of this group said that they had never heard about it. There was no significant difference among the group of married, singles and widow(er)s in the given answers to the questions if they had heard about organic farming and if so, where they had heard about it. The marital staus had no effect on the answers given. Asked how they could recognize organic products $20 \%$ of the married answered they could recognize them by the smell, $23 \%$ answered they asked the staff and $57 \%$ said they read the logo.

According to the marital status, there is a statistically significant difference in the answers to this question. The consumers' marital status affects the answers given. Fifty two percent of the male consumers who took part in the 
Table 3: Have you ever heard about organic farming products? If so, where did you hear about them?

\begin{tabular}{lccccccc}
\hline Marital status & Never heard & Intemet & Television & Radio & Newspaper & Friend & $\chi^{2}$ \\
\hline Married & 30 & 17 & 74 & 8 & 22 & 22 & 0.191 \\
Single & 23 & 19 & 41 & 14 & 13 & 17 & - \\
Widow(er) & 3 & 3 & 4 & 1 & 1 & 0 & - \\
\hline
\end{tabular}

Table 4: How can you recognize if a product is organic or not?

\begin{tabular}{lcccc}
\hline $\begin{array}{l}\text { Marital } \\
\text { status }\end{array}$ & $\begin{array}{c}\text { By the } \\
\text { smell }\end{array}$ & $\begin{array}{c}\text { By asking } \\
\text { the staff }\end{array}$ & $\begin{array}{c}\text { By reading } \\
\text { the logo }\end{array}$ & $\chi^{2}$ \\
\hline Married & 36 & 40 & 97 & $0.049^{*}$ \\
Single & 21 & 25 & 71 & - \\
Widow(er) & 2 & 7 & 3 & - \\
\hline
\end{tabular}

$* \mathrm{p}<0.01$ (significant)

Table 5: What do you attend to when you buy food?

\begin{tabular}{lcccc}
\hline Sex & $\begin{array}{c}\text { Contains } \\
\text { additives }\end{array}$ & Prize & Make & $\chi^{2}$ \\
\hline Male & 105 & 59 & 38 & $0.026^{*}$ \\
Female & 43 & 23 & 35 & - \\
\hline$* \mathrm{p}<0.01$ (significant) & & &
\end{tabular}

survey check for additives, $29 \%$ look at the prize and $19 \%$ prefer certain makes. The rates for female consumers is 42,23 and $35 \%$, respectively. The given answers are statistically significant related to sex. Also, the given answers to the question if the American regulation that organic food must be given to children from $0-2$ years of age should be applied in Turkey showed significant differences $(p<0.01)$. According to marital status, a significant difference could be found in the answers to the question how organic products could be recognized. The marital status affected the answers given (Table 3-5). Consumers have requested for healthier products in recent times. Goldman and Clancy (1991) reported consumers' worries about chemical residues in food. They pointed out that $40 \%$ of the consumers consumed organic products and $33 \%$ of the respondents thought that organic farming needed absolute support. In this respect, the gradually spreading organic farming plays a highly important role in offering safe food to consumers. Organic farming, which has become an important sector especially in Europe has not been developed sufficiently in Turkey yet. In this context, the result of this study about consumers' disposition towards organic farming has shown that many consumers are aware of organic farming and organic products. Eighty one percent of the consumers said that they had heard about organic farming products, while 19\% had not. Piyasiri and Ariyawordara (2002) reported in their study, which was conducted in the city of Kandy in Sri Lanka, that $91.1 \%$ of the consumers had heard about organic products and $81.1 \%$ consumed them. This rate covers the results of our study. Piyasiri and Ariyawordara (2002) also reported that $81 \%$ of the consumers found organic products expensive and $99 \%$ believed that organic products were of better quality and fresher. Organic farming offers potential for the Turkish export and there is no doubt that it will play an important role in Turkey's economy. Currently, a lot of consumers avoid to consume organic products because of their high costs. It is correct to connect the high prices of organic products with the fact that these products are not common or available permanently. If a product is available permanently and in a wide variety of offers, its price will settle down at a reasonable level.

\section{CONCLUSION}

This study shows that the higher the educational level of the consumer is the higher the acceptance for organic products is. In this context, most of consumers $(64 \%)$ connect the non-spread of organic products with a lack of information about organic farming and products. It is ineluctable that organic farming and its products will become an important sector in Turkey. The informing of the consumers about this system and the request for healthy food will advance this sector. Studies in wider perspective about this subject will help bring new results and insights in this context.

\section{REFERENCES}

Armagan, G. and M. Ozdogan, 2005. Consumption patterns of ecological egg and chicken meat and determining the consumer preferences. J. Anim. Prod., 46: 14-21.

Browne, A.W., P.J.C. Haris, H.A.H. Collins, N. Pasiecznik and R.R. Wallace, 2000. Organic production and ethical trade: Definition, practice and links. Food Policy, 25: 69-80.

Demir, A. and A. Pala, 2007. Perceptions of society towards genetically modified organisms. J. Anim. Prod., 48: 33-34.

Demiryurek, K., 2004. Organic agriculture in the world and Turkey. J. Agric Fac. HR.U., 8: 63-71.

Goldman, B.J. and K.L. Clancy, 1991. A survey of organic produce purchases and related attitudes of food cooperative shoppers. Am. J. Alternative Agric., 6: 89-96.

Lund, V. and B. Algers, 2003. Research on animal health and welfare in organic farming: A literatüre review. Livest. Prod. Sci., 80: 55-68. 
Piyasiri, A.G.S.A. and A. Ariyawordara, 2002. Market potentials and willingness to for selected organic vegatables in Kandy. Sri Lankan J. Agric. Econ., 4: $107-119$

Vindigni, G., M.A. Janssen and W.W. Jager, 2002. Organic food consumption: A multi-theoretical framework of consumer decision making. Br. Food J., 104: 624-642.
Yanmaz, R., 2001. Organic farming and organic fruit and vegetable production in Turkey. Ekin Dergisi, 5: 41-47.

Yussefi, M., 2004. Development and State of Organic Agriculture Word-Wide. In: The World of Organic Agriculture, Statistics and Emerging Trends, Wilier, H. and M. Yussefi (Eds.). 6th Edn., International Federation of Organic Agriculture Movements, Adelaide. 